Results of investigations in the five patients

\begin{tabular}{|c|c|c|c|c|c|c|}
\hline Investigation & Case 1 & Case 2 & Case 3 & Case 4 & Case 5 & Normal range \\
\hline $\begin{array}{l}\text { Calcium concentration at presentation (corrected value; } \mathrm{mmol} / \mathrm{l}) \\
\text { Phosphate concentration at presentation (mmol/l) } \\
\text { Chloride concentration at presentation (mmol/l) } \\
\text { Alkaline phosphatase activity at presentation (U/1) } \\
\text { Parathyroid hormone value (U/1) } \\
\text { Bone scan appearances } \\
\text { Skeletal survey result } \\
\text { Histological findings }\end{array}$ & $\begin{array}{l}3 \cdot 96 \\
0.70 \\
107 \\
158 \\
<0 \cdot 80 \\
\text { Normal } \\
\text { Normal } \\
\text { Papillary } \\
\text { cystadeno- } \\
\text { carcinoma }\end{array}$ & $\begin{array}{l}3 \cdot 14 \\
0 \cdot 81 \\
92 \\
130 \\
<0 \cdot 20 \\
\text { Normal } \\
\text { Normal } \\
\text { Clear cell } \\
\text { carcinoma }\end{array}$ & $\begin{array}{l}3 \cdot 49 \\
0 \cdot 80 \\
\text { ND } \\
150 \\
0 \cdot 16 \\
\text { Normal } \\
\text { ND } \\
\text { Serous } \\
\text { cystadeno- } \\
\text { carcinoma }\end{array}$ & $\begin{array}{l}3 \cdot 06 \\
1 \cdot 20 \\
104 \\
140 \\
<0 \cdot 20 \\
\text { ND } \\
\text { ND } \\
\text { Clear cell } \\
\text { carcinoma }\end{array}$ & $\begin{array}{l}2 \cdot 72 \\
0.80 \\
107 \\
150 \\
\text { ND } \\
\text { ND } \\
\text { ND } \\
\text { Papillary } \\
\text { cystadeno- } \\
\text { carcinoma }\end{array}$ & $\begin{array}{c}2 \cdot 25-2 \cdot 50 \\
0.87-1 \cdot 45 \\
95-105 \\
30-140 \\
0 \cdot 20-0 \cdot 60\end{array}$ \\
\hline
\end{tabular}

$\mathrm{ND}=$ Not done

Conversion: SI to traditional units-Calcium: $1.0 \mathrm{mmol} / 1 \approx 4.0 \mathrm{mg} / 100 \mathrm{ml}$. Phosphate: $1.0 \mathrm{mmol} / 1 \approx 3.1 \mathrm{mg} / 100 \mathrm{ml}$. Chloride: $1.0 \mathrm{mmol} / \mathrm{l}=1.0 \mathrm{mEq} / 1$.

centration remained between $2 \cdot 70$ and $2.90 \mathrm{mmol} / 1(10.8$ and $11.6 \mathrm{mg} /$ $100 \mathrm{ml}$ ) until near her death, 14 months later, when it rose sharply. She remained asymptomatic of hypercalcaemia throughout.

\section{Comment}

In none of these patients was there evidence of bone metastases. Paraneoplastic hypercalcaemia occurs in $5-10 \%$ of malignancies and has been reported in ovarian carcinoma. ${ }^{12}$ Fisken et al, however, found that 89 out of 159 hospital inpatients with hypercalcaemia had malignant disease, but none had ovarian carcinoma. ${ }^{3}$ Our five patients represented a high incidence in our practice, being among 70 new patients seen over 18 months. Two of the patients had clear cell carcinoma, and in the few other reports this tumour has been disproportionately represented.1 ${ }^{245}$ The mechanism of paraneoplastic hypercalcaemia in ovarian cancer is obscure but the biochemical findings in our patients were compatible with production of a parathyroid-hormone-like substance.

Paraneoplastic hypercalcaemia due to ovarian carcinoma may be more common than previously suggested. It is an important association, since the symptoms of hypercalcaemia may be mistaken for intestinal obstruction (a common preterminal event in ovarian carcinoma), as exemplified by our case 3 . Patients may also present afresh or with recurrence of disease and be found to have life threatening hypercalcaemia requiring urgent treatment.

\section{References}

1 Stewart AF, Romero R, Schwartz PE, Kohorn EI, Broadus AE. Hypercalcemia associated with gynecologic malignancies. Cancer 1982;49: 4389-94.

2 Powell D, Singer FR, Murray TM, Minkin C, Potts JT. Non parathyroid humoral hypercalcemia in patients with neoplastic diseases. $N$ Englf Med $1973 ; 289: 176-81$

${ }^{3}$ Fisken RA, Heath DA, Somers S. Hypercalcaemia in hospital patients: clinical and diagnostic aspects. Lancet 1981 ; :202-7.

${ }^{4}$ Ferenczy A, Okgaki T, Richart RM. Para-endocrine hypercalcemia in ovarian neoplasms. Report of mesonephroma with hypercalcemia and review of the literature. Cancer $1971 ; 27: 427-31$.

${ }^{5}$ Holty G, Johnston JR, Shrock ME. Paraneoplastic hypercalcemia in ovarian tumors. Obstet Gynecol 1979;54:483-7.

(Accepted 15 March 1984)

\title{
Subcutaneous terbutaline and control of brittle asthma or appreciable morning dipping
}

\author{
JON AYRES，D R FISH，D C WHEELER，J WIGGINS， G M COCHRANE，CRAIG SKINNER
}

\begin{abstract}
In a pilot study two patients with brittle asthma and two with morning dipping received terbutaline or a placebo administered subcutaneously either by continuous infusion or in injections every six hours. In two patients brittle asthma was completely suppressed by terbutaline
\end{abstract}

\footnotetext{
Department of Chest Medicine, East Birmingham Hospital, Birmingham B9 5ST

JON AYRES, MB, MRCP, senior registrar

D C WHEELER, MB, MRCP, senior house officer

J WIGGINS, MB, MRCP, registrar

CRAIG SKINNER, MB, FRCP, consultant physician

Department of Thoracic Medicine, New Cross Hospital, London SE14 5ER

D R FISH, $M B, M R C P$, senior house officer

G M COCHRANE, MB, MRCP, consultant physician

Correspondence to: Dr Jon Ayres.
}

$1 \mathrm{mg} /$ day given by either method. In the two others early morning dipping responded only to continuous subcutaneous infusions of terbutaline $12 \mathrm{mg} / \mathrm{day}$.

Terbutaline administered subcutaneously may be an effective treatment in asthmatic patients who show important diurnal variations in air flow.

\section{Introduction}

Some patients with asthma-for example, patients with brittle asthma or morning dipping ${ }^{1}$ - show considerable changes in air flow throughout the day despite maximal treatment. In a pilot study we used subcutaneous administration of terbutaline to treat two patients with brittle asthma and two with morning dipping.

\section{Methods}

We studied one woman aged 19 and three men aged 29,35 , and 44 . All had diurnal variation in peak expiratory flow rate of at least $40 \%$ 
despite daily prednisolone $(15,30,30$, and $30 \mathrm{mg}$ ), therapeutic doses of oral theophyllines, daily nebulised salbutamol $(50 \mathrm{mg})$, ipratropium bromide $(2.5 \mathrm{mg})$, and high doses of inhaled steroids. Three of the patients were also taking oral $\beta_{2}$ agonists. The study was a double blind, placebo controlled, within patient comparison of terbutaline given in the same daily dose either by continuous subcutaneous infusion or in four subcutaneous injections, one every six hours.

Each patient was studied on three occasions in hospital. Each of the three occasions comprised a four day run in period during which the patient's usual treatment was continued and five days during which treatment was changed. During the first two periods in hospital the patient's usual oral and inhaled $\beta_{2}$ agonists were withdrawn after the run in period; on the first occasion the patient then received terbutaline by continuous subcutaneous infusion and placebo (saline) in four subcutaneous injections, one every six hours; on the second occasion the patient received placebo by continuous subcutaneous infusion and terbutaline in four subcutaneous injections, one every six hours. During the third period in hospital the patient's usual $\beta_{2}$ agonist treatment was continued during the treatment period and saline given both by continuous subcutaneous infusion and in four subcutaneous injections (double placebo). The dose of terbutaline was $14 \mu \mathrm{g} / \mathrm{kg} /$ day $(1 \mathrm{mg} /$ day for a man weighing $70 \mathrm{~kg}$ ). The peak expiratory flow rate (best of three values) was recorded hourly and pulse rate and blood pressure every four hours throughout each period in hospital. Statistical analysis was carried out using the Mann-Whitney U test.

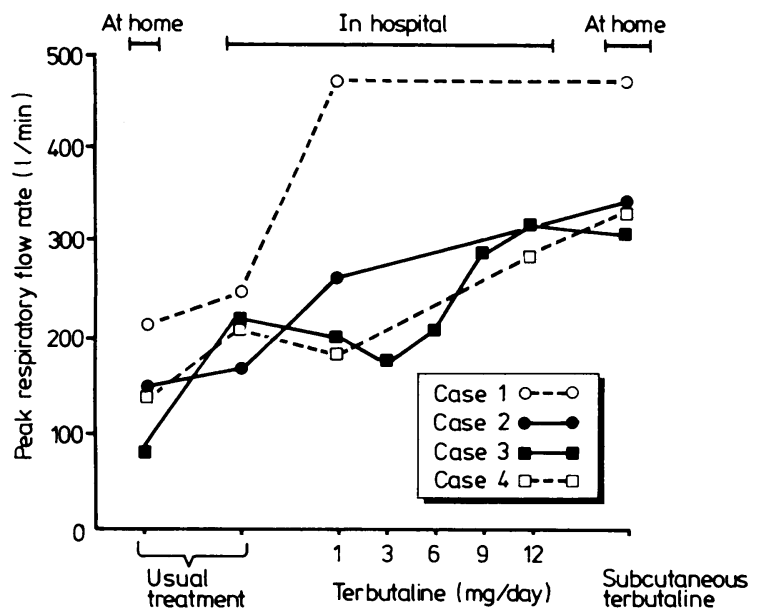

Mean lowest daily peak expiratory flow rate while patients were at home receiving standard treatment, in hospital and at home receiving subcutaneous terbutaline $(1 \mathrm{mg} /$ day in divided doses in cases 1 and $2 ; 12 \mathrm{mg} /$ day by continuous subcutaneous infusion in cases 3 and 4 ).

\section{Results}

In one patient (case 1) the mean lowest daily peak expiratory flow rate rose from 254 to $474 \mathrm{l} / \mathrm{min}$ (an increase of $87 \%(\mathrm{p}<0.001)$ ) with divided doses (figure) and from 133 to $296 \mathrm{l} / \mathrm{min}$ (an increase of $123 \%$ $(\mathrm{p}<0.001))$ with continuous subcutaneous infusion. Another patient (case 2) also showed an improvement in her mean daily peak expiratory flow rate both with divided doses $(170-266 \mathrm{l} / \mathrm{min}$, an increase of $57 \%(p<0.02)$ ) (figure) and with continuous subcutaneous infusion $(288$ to $360 \mathrm{l} / \mathrm{min}$, an increase of $58 \%(\mathrm{p}<0.001))$. These two patients showed no change in peak expiratory flow rate with placebo. The two other patients (cases 3 and 4) showed no change in air flow during any of the three periods in hospital. Their blood pressures and pulse rates remained unchanged throughout.

Two patients (cases 1 and 2) subsequently received subcutaneous injections of terbutaline at home every six hours. In both all oral steroid and nebulised bronchodilator treatment could then be stopped, and neither was admitted to hospital in the subsequent 36 (case 1) or 48 (case 2) weeks, though they had been admitted six and 12 times respectively in the previous year.

One patient (case 3 ) received serially increasing doses of continuous subcutaneous infusion of terbutaline as replacement for his oral and inhaled $\beta_{2}$ agonists. There was a clear improvement, related to dose, in mean lowest daily expiratory flow rate (figure). He was then sent home, and after 29 days of treatment with terbutaline $12 \mathrm{mg} /$ day his asthma was well controlled, he required only occasional doses of nebulised salbutamol, and his steroid dose had been reduced from 30 to $20 \mathrm{mg}$ daily. The remaining patient (case 4) was treated with $12 \mathrm{mg}$ terbutaline daily by continuous subcutaneous infusion (instead of his usual $\beta_{2}$ agonist treatment). His mean lowest daily peak expiratory flow rate rose from 148 to $288 \mathrm{l} / \mathrm{min}(\mathrm{p}<0.001)$. After 14 weeks' follow up at home he had stopped all treatment with oral steroids and aminophylline.

When receiving nebulised salbutamol two patients (cases 3 and 4) had severe tremor and tachycardia without control of their asthma, whereas terbutaline given by continuous subcutaneous infusion controlled their asthma without side effects. Another patient (case 2) initially had small haematomas at the sites of injection, but these cleared when her steroid dose was reduced.

\section{Discussion}

In all four patients terbutaline given subcutaneously improved control of asthma, both subjectively and objectively, and other treatment, notably oral steroids, could be reduced. Adrenaline concentrations are low at night in patients with nocturnal asthma, ${ }^{2}$ and nocturnal falls in peak expiratory flow rate can be corrected with infusions of adrenaline. ${ }^{3}$ Oral slow release salbutamol is ineffective in morning dipping, ${ }^{4}$ although slow release aminophylline gives small improvements in morning peak expiratory flow rate. ${ }^{5}$ This pilot study suggests that subcutaneous terbutaline, possibly acting by stimulation of $\beta_{2}$ receptors on smooth muscle or mast cells, or both, may prove an effective treatment in patients who show considerable diurnal variations in air flow.

We thank Miss D Kirby and Miss C Reed for preparing the terbutaline solutions and Mrs M A Jervis for secretarial help.

\section{References}

1 Warwick MT. On observing patterns of airflow obstruction in chronic asthma. $\mathrm{Br} 7$ Dis Chest 1977;71:73-86.

2 Barnes P, Fitzgerald G, Brown M, Dollery C. Nocturnal asthma and changes in circulating epinephrine, histamine and cortisol. $N$ Engl $\mathcal{f}$ Med $1980 ; 303: 263-7$

${ }^{3}$ Barnes P, Fitzgerald GA, Dollery CT. Circadian variation in adrenergic responses in asthmatic patients. Clin Sci 1982;62:349-54.

4 Fairfax AJ, McNabb WR, Davies HJ, Spiro SG. Slow release oral salbutamol and aminophylline in nocturnal asthma: relation of overnight changes in lung function and plasma drug levels. Thorax 1980;35:52630.

${ }^{5}$ Barnes PJ, Greening AP, Neville L, Timmers J, Poole GW. Single dose slow release aminophylline at night prevents nocturnal asthma. Lancet 1982 ; :299-301.

(Accepted 29 March 1984)

ONE HUNDRED YEARS AGO We publish this week a letter from a correspondent on the practice of uncovering the head at funerals. We quite agree with him that the practice is often highly prejudicial to the health of mourners, who may have many living persons dependent upon them, and who are exposed by the custom to actual risk of life, or at least to a very great chance of being seized with temporary indispositions, which are certain to cause them unfair and needless inconvenience. The depression of spirits under which the chief mourners labour at these melancholy occasions, peculiarly predisposes them to some of the worst direct and indirect effects of chill; and even when any person is present at a burial out of respect to the deceased, with whom he has had none of the deep sympathy due to relationship or intimacy, the risk of his catching cold is considerable, as a visitor of this kind has often walked some distance or travelled in a hot carriage by rail or road. A duty of this kind is often pressed upon a medical man; and in his case the risk is great, and the result of any consequent illness often very serious. It is, however, very difficult to break old customs without giving offence; and perhaps the best thing to do, under the circumstances, is for the mourner to wear a skull-cap, or to raise his hat as little from his head as possible, as both these subterfuges appear to be conventionally permissible. (British Medical fournal $1884 ;$; : 1163.) 